\title{
FORMATION EVALUATION OF THE PETROPHYSICAL PROPERTIES OF WELLS IN E - FIELD ONSHORE NIGER DELTA, NIGERIA
}

\author{
M. Ilevbare ${ }^{1}, *$ and 0. M. Omorogieva ${ }^{2}$ \\ 1, Department of Geology, Faculty of Physical SCIENCES, University of Benin, Edo State, NIGERIA \\ 2, DePt OF Marine Geology, Nigerian Maritime UniverSity, OKerenKoKo, Delta State, NIGERIA \\ Email addresses. ${ }^{1}$ ilevbaremartins777@gmail.com ${ }^{2}$ osakpolor.omorogieva@physci.uniben.edu
}

\begin{abstract}
Integrated wireline logs and lithostratigraphic techniques were employed to determine the lithological and petrophysical properties of wells $A$ and B in E- field, onshore Niger Delta. The Reservoirs in both wells were analyzed using a minimum thickness or depth of penetration of 5.0m. For the two wells, Gas Water Contact (GWC), Gas Oil Contact (GOC), and Oil Water Contact (OWC) were found to be present at varying formation depths. GWC, GOC, and OWC at depth of $2967.50 \mathrm{~m}, 3348 \mathrm{~m}$ and $2286 \mathrm{~m}$ respectively for well $A$ and a GOC at depth $1715 \mathrm{~m}$ for well $B$. The correlation of both wells reveals a gas reservoir, water reservoir, and a non-resistive, but highly conductive zone at $2450 \mathrm{~m}, 2500 \mathrm{~m}$, and $2150 \mathrm{~m}$ depth respectively. The formation porosity $\left(\emptyset_{D}\right)$, total porosity $\left(\emptyset_{T}\right)$, effective porosity $\left(\emptyset_{E}\right)$ and resistivity values of well A ranges from (27.27 $39.59) \%,\left(1.3 \times 10^{-1}-37.82\right) \%,\left(1.638 \times 10^{-4}-81.38\right) \%,(2.05-150) \Omega m$ respectively. Conversely, well B measured (27.27 - 36.50) \%, (2.25x10-2 - 93.0) \%, $\left(9.75 \times 10^{-4}-32.79\right) \%$ and $(2-200) \Omega m$ respectively. Hydrocarbon saturation ( $S_{H C}$ ) and Bulk volume of Hydrocarbon (BVH) for well $A$ ranges from (73.27-95.10)\% and (24.24 - 34. 58)\% while that of well $B$ ranges from (77.10 - 97. 90)\% and (23.36 - 35.53)\% for $S_{H C}$ and BVH respectively. The average $\emptyset_{T}$ and $\emptyset_{E}$ of $56.2 \%$ and $42.6 \%$ reveal excellent porosities in well $A$ and reservoirs $2,3,4 a$ and 11 in well $B$ with average $\emptyset_{T}$ and $\emptyset_{E}$ of $37.82 \%$ and $30.6 \%$ also show an excellent porosities. The result from the Petrophysical indices indicates pay zones at reservoirs 10a, 10b and 11 in well $A$ and reservoir 11 in well $B$ which are predominantly gas reserves.
\end{abstract}

Keywords: Reservoirs, Onshore, Oil and Gas, Petrophysical properties, Niger Delta and Lithology

\section{INTRODUCTION}

Short and Stauble [1] first gave a detailed description of the chronostratigraphic units of the Niger Delta Basin which is composed of the Akata, Agbada and Benin Formations from the oldest to the youngest. A clue to the sedimentology of these units was the literary contributions of Allen [2-3].

Studies on reservoir characteristics and the various aspects of petroleum geology have been discussed in Weber and Daukoru [4-6].

Allen [2] categorized recent deposition in the Niger Delta into sub-environments comprising Upper flood plain, Lower flood plain mangrove swamp, beach barrier, River Mouth, Delta front platform, Pro-delta slope and open shelf.

Further work was done by Allen $[2,4]$ on the classification of Niger Delta environments. Weber and Daukoru [4], classified the Niger Delta deposits into five sub-environments viz; Holomarine (marine shale and transgressive marine sand), barrier foot (laminated barrier foot sand), barrier bars (Barrier bar sands), tidal coastal plains (point bar and tidal channel deposits) and lower deltaic flood plain (fluviatile back swamp deposits). The Niger Delta is the failed arm of a triple junction system (aulacogen) that originally developed during the breakup of the South American and African plates in the late

\footnotetext{
* Corresponding author, tel: +234-905-719-9940
} 
Jurassic [7-8]. The two arms that followed the southwestern and southeastern coasts of Nigeria and Cameroon developed into the passive continental margin of West Africa, whereas the third failed arm formed the Benue Trough. Other depocenter along the African Atlantic coast also contributed to deltaic build-up Synrift sediments accumulated during the Cretaceous to Tertiary, with the oldest dated sediments of the Albian age [9]. Thickest succession of syn-rift marine and marginal marine clastics and carbonates were deposited in a series of transgressive and regressive phases [10]. The synrift phase ended with basin inversion in the Santonian (Late Cretaceous). Renewed subsidence occurred as the continents separated and the sea transgressed the Benue trough. The Niger Delta clastic wedge continued to prograde during middle cretaceous time into a depocentres located above the collapsed continental margin at the site of the triple junction. Sediment supply was mainly along drainage systems that followed two failed rift arms, the Benue and Bida Basins. Sediment progradation was interrupted by episodic transgression during late Cretaceous time. During the Tertiary, sediment supply was mainly from the north and east through the Niger, Benue and Cross River.

The Niger Delta Basin is situated on the continental margin of the Gulf of Guinea in equatorial West Africa, between latitude $3^{\circ}$ and $6^{\circ} \mathrm{N}$ and longitude $5^{\circ}$ and $8^{\circ} \mathrm{E}$. It ranks among the world most prolific petroleum producing tertiary deltas and accounts for about $5 \%$ of the world's oil and gas reserves. The Benin flank, which is the subsurface continuation of the West African Shield, marks the northwestern rim of the Basin. This gently plunging monoclonal flank terminates along a SW - NE trending flexure or fault zone, the Hinge line. At the eastern fringe of the Basin, there is a similar but more complex feature, the Calabar flank that is the subsurface continuation of the Oban massif. The Calabar flank breaks off along the Calabar Hinge line which trends in a NW SE direction. To the North of the basin lies the Abakaliki uplift and the Anambra Basin. The Niger Delta Basin has built out the central Atlantic at the mouth of the Niger-Benue and Cross River drainage systems. The Delta stretches for about $300 \mathrm{~km}$ from apex to mouth and covers an area of at least $75000 \mathrm{~km}^{2}$ [10].

Growth faults strongly influenced the sedimentation pattern and thickness distribution of sand and shales. Nearly all hydrocarbon accumulations are associated with rollover structures formed along growth fault or with other closure against these faults [11]. Individual fault blocks can be grouped into macro and eventually, mega structural units that constitute separate provinces with regard to time stratigraphy, sedimentation, deformation, generation, Migration and distribution of hydrocarbon [12]. The Niger Delta (Akata-Agbada) province contains only one identified petroleum system [13]. The maximum extent of the petroleum system coincides with the boundaries of the Niger Delta province. The minimum extent of fields and contains known resources. Cumulative production plus proven reserves of 34.5 billion barrels of oil (BBO) and 93.8 trillion cubic feet of gas (TCFG), 14.9 Billion barrels of oil equivalent, $\mathrm{BBOE}$ ) petro consultants [14]. Currently, most of the petroleum field onshore is found in water less than 200 metres deep, and occurs primarily in large, relatively simple structures.

Source rocks in the Niger Delta might include marine interbedded shale in the Agbada Formation, marine Akata Formation shales and underlying Cretaceous shales [5, 10, 15-16]

Reservoir intervals in the Agbada Formation have been interpreted to be deposits of high stand and transgressive system tracts in proximal shallow ramp settings [5]. The reservoirs range in thickness from less than 45 feet to a thickness greater than 150 feet. Structural traps formed during synsedimentary deformation of the Agbada Formation and Stratigraphic traps formed preferentially along the delta flanks define the most common reservoir locations within the Niger Delta Complex. The primary seal rocks are interbedded shales within the Agbada Formation. Three types of seals are recognized by clay smears along faults, interbedded sealing units juxtaposed against reservoir sands due to faulting and vertical seals, produced by laterally continuous shale rich strata.

The current study employed wireline logging in evaluating the petrophysical properties of well $A$ and $B$ in E-Field onshore Niger Delta in determining their potentiality in oil and gas production. The experiment was performed by lowering a "logging tool" on the end of a wireline into an oil well (or borehole) and recording petrophysical properties using a variety of sensors. Logging tools developed over the years measured the electrical, acoustic, radioactive, electromagnetic, nuclear magnetic resonance, and other properties of the rock and the 
fluids contained in them [17-19]. The outcome of the study will provide a robust data set for oil and gas prospecting companies as well as a baseline study for further research in the area of study.

\section{STUDY AREA}

The study area ( $E$ - Field) is located in OPL 98 (onshore), it lies within the Northwestern part of the Niger Delta. The field was discovered in 1980 by Nigeria Petroleum Development Company (Figure 1).

\section{METHODOLOGY}

Wireline logs were obtained on a written request from Nigeria Petroleum Development Company (NPDC) and the Department of Petroleum Resources (DPR). The data set on a scale of 1:500 from $E$ field onshore Niger Delta contained two wells A and B (Figures 2 and 3). The log types include gamma-ray logs, resistivity logs, and a combination of neutron/density logs. Wireline logs were divided into three (3) categories which include; Electrical logs (resistivity log), Porosity logs (density logs, neutron logs, sonic logs) and Lithology logs (gamma-ray logs, self/spontaneous potential logs).

\section{EVALUATION TECHNIQUES}

\subsection{Lithostratigraphic Analysis}

Identification of lithology defined strictly based on lithic criteria such as the description of actual rock material from gamma-ray log. Secondly for the identification of the gamma-ray deflection whereby, deflection to the right is an indication of a shaly unit while to the left is a sand body or carbonate interval.

\subsection{Lithologic Correlation}

This is achieved from the gamma-ray log responses by linking marker horizon as the physical properties of the formation across the well. Correlation allows the geologist to map Formation depth and thickness as well as identify conditions that would trap hydrocarbon. It is usually based on the shape of the recorded curves versus depth. Correlation in complex geologic environments may be difficult or impossible and in any event requires corroboration from actual rock samples for the initial correlation in an area. After the curve shape patterns are recognized, they can often be used in subsequent wells, without relying so much on rock sample data.

\subsection{Determination of Porosity}

This measurement is significant because it tells how much storage space a rock has for fluids. No log measures porosity directly, but many analytical methods are available to help estimate this important property. In other to ascertain the consistency of the porosities, neutron-density log was used by plotting the bulk density $\left(\rho_{b}\right)$ and neutron density $\left(\rho_{n}\right)$ on the $X$-plot and determining lithology and porosity estimate on each lithologic line (Figure 4). The cross plot was also used to correct the porosity of gas bearing reservoirs.

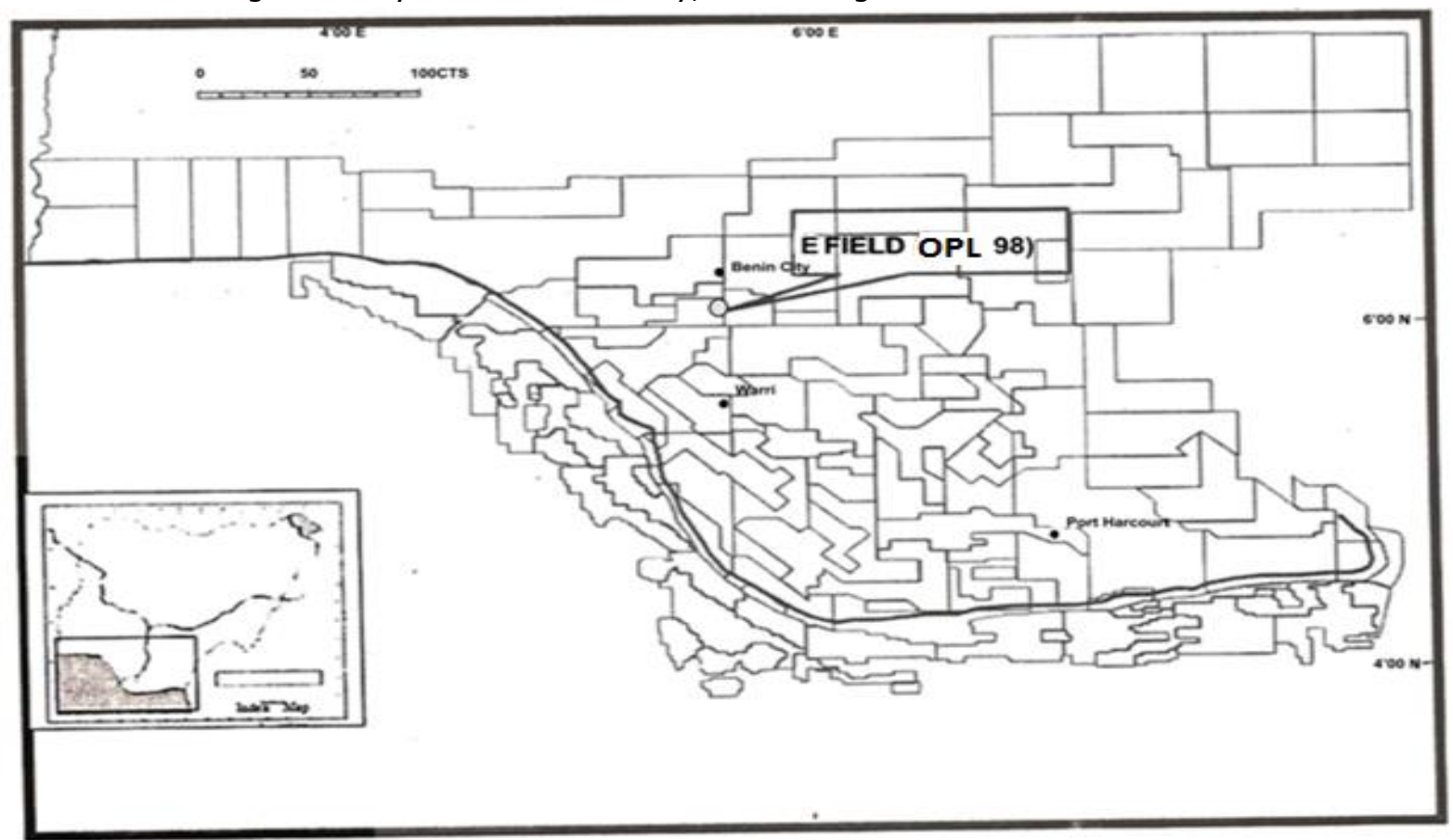

Figure 1: Concession map of western Niger Delta with arrow indicating OPL 98 and the position of E- field [20] 

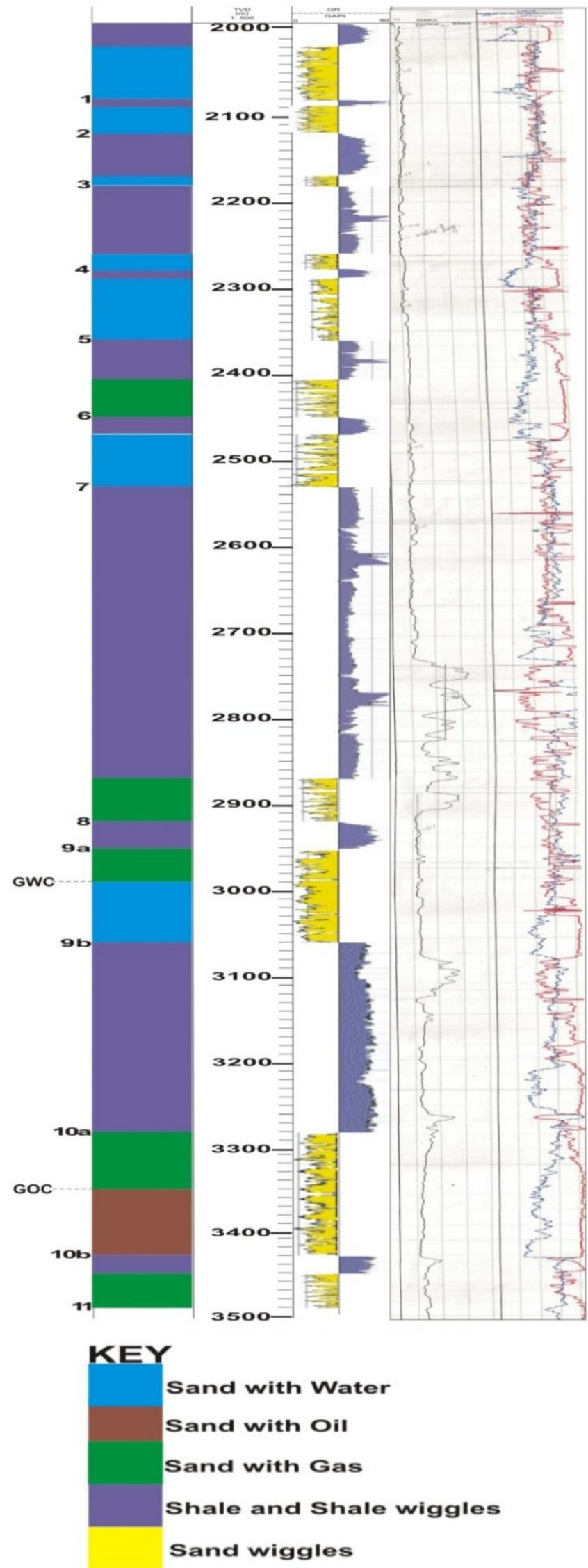

Figure 2: Prolific section of well $\log$ A field E onshore Niger Delta
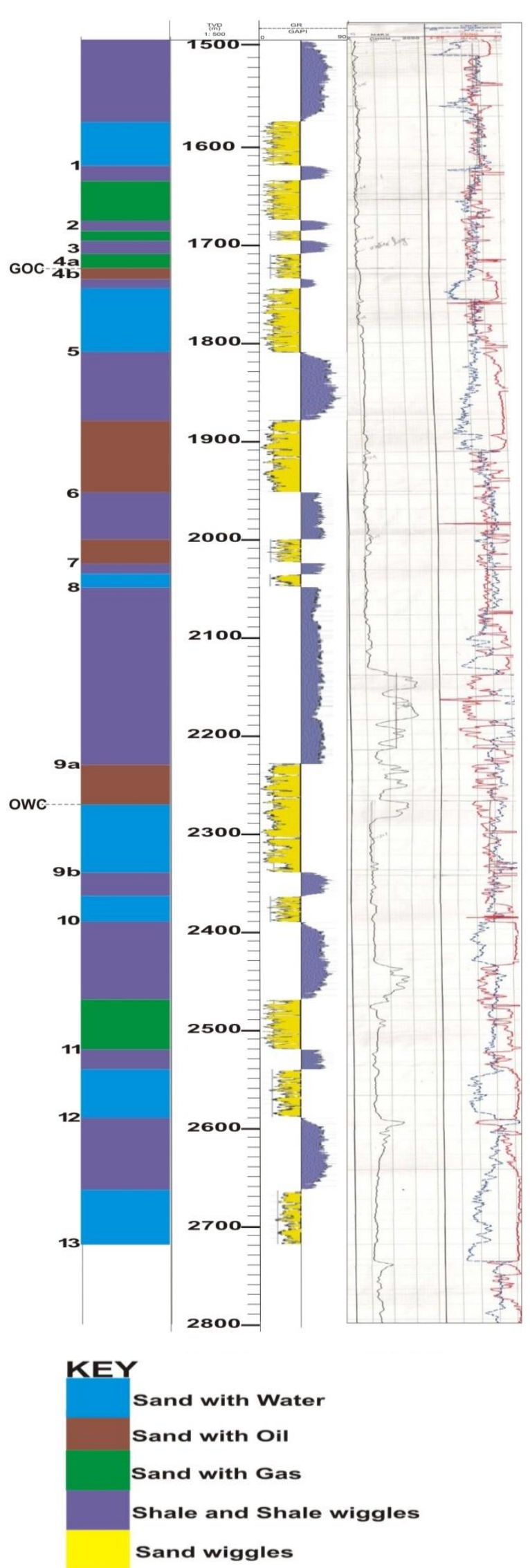

Figure 3: Prolific section of well $\log B$ in field $E$ onshore Niger Delta 


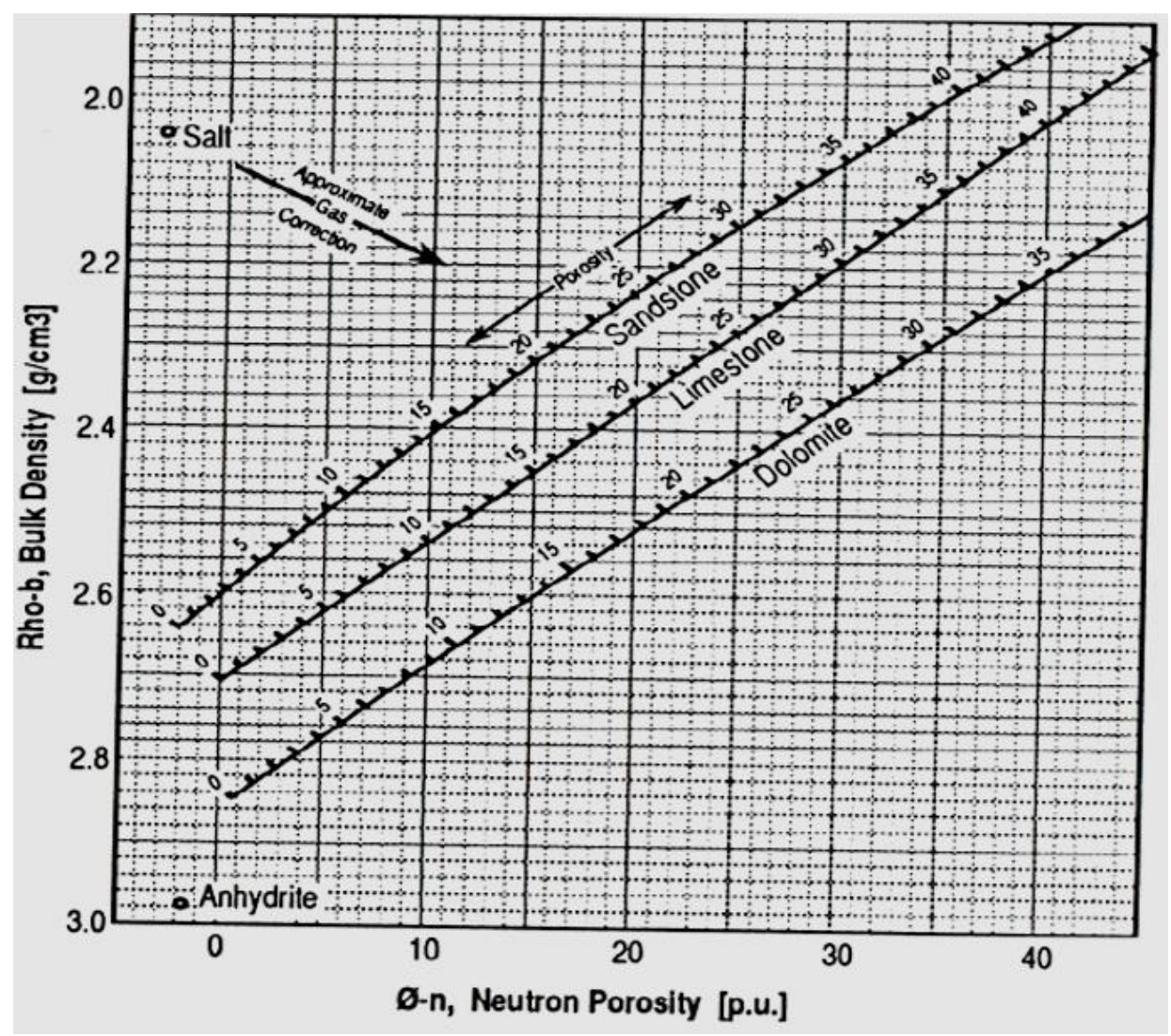

Figure 4: Density-neutron cross plot Modified after [21].

\section{RESERVOIR EVALUATION}

A routine use of well log is the determination of the water, oil or gas saturation in the rock pores. When the porosity of oil or gas saturation, the thickness and extent of the reservoir are known, then it is possible to tell how much hydrocarbon is in place in the reservoir. The movement of fluid in and near the well is very important because such measurement can indicate channels behind casing, casing leaks, tubing leaks, water influx problems, cross-flow from one reservoir to another and other production problems. Another common use of this fluid flow measurement is the determination of water input profiles in water injection wells. Networks of mathematical formulae were applied in computing the petrophysical parameters in Table 1 and Table 2 respectively.

The formulae are shown below;

$$
\begin{aligned}
\emptyset_{D} & =\frac{\ell_{m a}-\ell_{b}}{\ell_{m a}-\ell_{f l}} \\
\emptyset_{T} & =\frac{\emptyset_{N}^{2}-\emptyset_{D}^{2}}{2} \\
V_{S H} & =\frac{G R \log -G R_{m m}}{G R_{\text {Max }}-G R_{m m}} \\
\emptyset_{E} & =\emptyset_{T} \times\left(1-V_{S H}\right)
\end{aligned}
$$

$$
\begin{aligned}
& R_{w}=R_{o} \times \emptyset_{D}^{m} \\
& S_{w}=\frac{a-R_{w}}{\left(\emptyset_{D}^{m}-R t\right)^{1 / n}} \\
& S_{H C}=1-S_{w} \\
& B V W=\emptyset_{D} \times S_{w} \\
& B V H=\emptyset_{D} \times\left(1-S_{w}\right)=\emptyset_{D} \times S_{H C}
\end{aligned}
$$

Where; $\emptyset_{D}=$ porosity of formation in $\% ; \ell_{m a}=$ matrix porosity $=2.65$ for sandstone; $\ell_{b}=$ bulk density $\left(\mathrm{G} / \mathrm{C}^{3}\right) ; \ell_{f l}=$ fluid porosity which is 1 for fresh water/oil; $\emptyset_{T}=$ average total porosity (\%); $\emptyset_{N}=$ neutron porosity $(\%) ; V_{S H}=$ volume of shale (\%); $G R_{\min }=$ sand line reading; $G R_{\operatorname{Max}}=$ shale line reading; $G R \log =$ gamma ray formation rending usually intermediate between sand line and the cutoff line; $\emptyset_{E}=$ effective porosity (\%); $R_{w}=$ resistivity of water $(\Omega \mathrm{m}) ; R_{o}=$ resistivity of the water bearing leg.

$R_{t}=$ true formation resistivity as measured by deep reading resistivity log; $S_{w}=$ water saturation (\%); $S_{H C}=$ hydrocarbon saturation (\%); BVW = bulk volume of water $(\%) ; \mathrm{BVH}=$ bulk volume of hydrocarbon $(\%) ; \mathrm{m}=$ cementation factor $=2$ for sandstone; $\mathrm{n}=$ saturation exponent $=2$ and $\mathrm{a}=$ Archie' constant $=2$ 


\begin{tabular}{|c|c|c|c|c|c|c|c|c|c|}
\hline 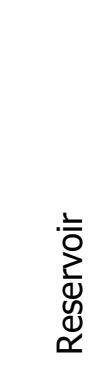 & 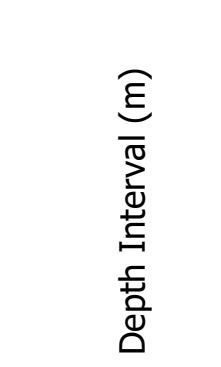 & 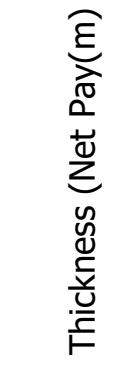 & 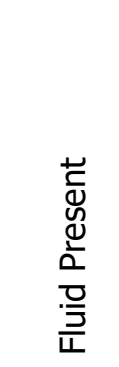 & 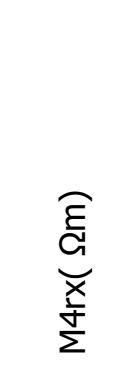 & 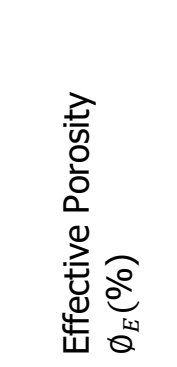 & 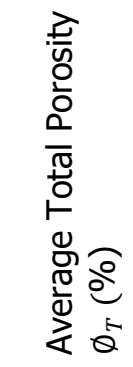 & 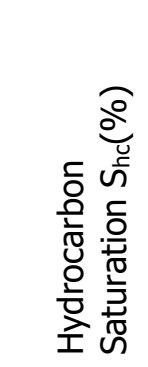 & 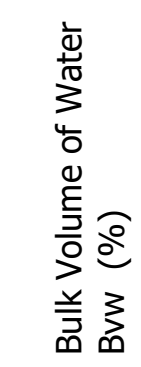 & 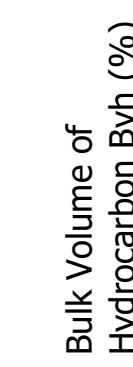 \\
\hline 1. & $2008-2082.5$ & 74.50 & Water & 2.05 & 1.07 & 1.29 & - & 27.27 & - \\
\hline 2. & 2085-2102.5 & 17.50 & Water & 2.10 & 1.46 & 1.82 & - & 30.30 & - \\
\hline 3. & $2168-2185$ & 17.00 & Water & 2.10 & 0.75 & 1.32 & - & 33.30 & - \\
\hline 4. & $2265-2270$ & 5.00 & Water & 2.10 & $1.64 \times 10^{-4}$ & 0.0225 & - & 30.30 & - \\
\hline 5. & $2288-2368$ & 80.00 & Water & 2.00 & 1.7 & 2.67 & - & 27.27 & - \\
\hline 6. & $2406-2453$ & 47.00 & Gas & 60.00 & 20.37 & 38.19 & 92.26 & 2.81 & 33.55 \\
\hline 7. & $2485-2532$ & 47.00 & Water & 2.10 & 55.96 & 67.16 & - & 39.39 & - \\
\hline 8. & $2878-2913$ & 35.00 & Gas & 40.00 & 31.44 & 58.98 & 90.52 & 3.45 & 32.91 \\
\hline 9a. & 2923-2967.5 & 44.50 & Gas & 40.00 & 57.99 & 66.91 & 90.52 & 3.45 & 32.91 \\
\hline 9b. & 2967.5-3054 & 86.50 & Water & 2.20 & 59.56 & 68.72 & - & 37.58 & - \\
\hline 10a. & $3292-3348$ & 56.00 & Gas & 150.00 & 49.13 & 58.98 & 95.10 & 1.78 & 34.58 \\
\hline 10b. & $3348-3417.5$ & 69.50 & Oil & 6.00 & 15.50 & 21.02 & 73.27 & 8.90 & 24.40 \\
\hline 11. & $3425-3449$ & 24.0 & Gas & 6.00 & 81.38 & 93.00 & 75.52 & 8.90 & 27.46 \\
\hline
\end{tabular}

Table 2: Calculated Petrophysical parameters of reservoir sand for Well log B

\begin{tabular}{|c|c|c|c|c|c|c|c|c|c|}
\hline 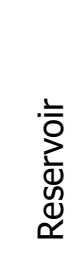 & 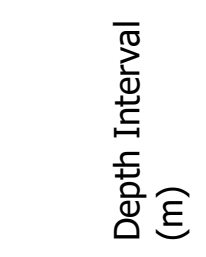 & 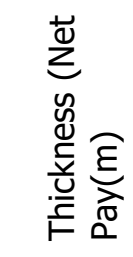 & 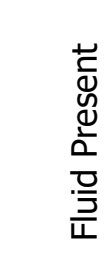 & 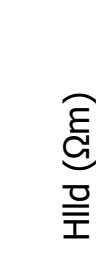 & 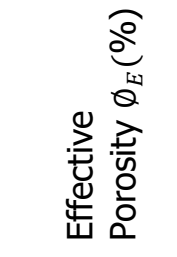 & 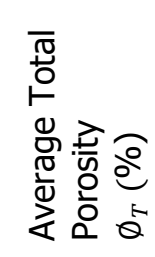 & 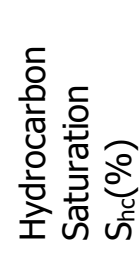 & 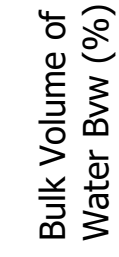 & 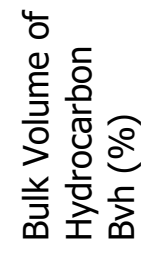 \\
\hline 1 & $1574-1610$ & 36.00 & Water & 2 & 2.36 & 2.72 & - & 33.00 & - \\
\hline 2 & $1647-1661$ & 14.00 & Gas & 200 & 28.36 & 37.82 & 97.9 & 0.76 & 35.53 \\
\hline 3 & $1666-1680$ & 14.00 & Gas & 100 & 32.79 & 37.82 & 97.0 & 1.08 & 35.21 \\
\hline $4 a$. & $1708-1715$ & 7.00 & Gas & 140 & 32.79 & 37.82 & 97.02 & 0.91 & 35.22 \\
\hline 4b. & $1715-1724$ & 9.00 & Oil & 16 & 6.28 & 9.92 & 91.89 & 2.70 & 30.60 \\
\hline 5. & $1735-1803$ & 68.00 & Water & 2 & 2.22 & 2.67 & - & 27.27 & - \\
\hline 6. & 1876-1966 & 90.00 & Oil & 4 & $9.75 \times 10^{-4}$ & $1.3 \times 10^{-1}$ & 80.20 & 5.40 & 21.87 \\
\hline 7. & $2003-2014$ & 11.00 & Oil & 4 & 8.26 & 9.92 & 82.18 & 5.40 & 24.90 \\
\hline 8. & $2048-2168$ & 120.00 & Water & 2 & 2.00 & 2.67 & - & 27.27 & - \\
\hline 9a. & $2281-2286$ & 5.00 & Oil & 8 & 22.09 & 26.52 & 77.10 & 6.94 & 23.36 \\
\hline 9b. & $2286-2340$ & 52.00 & Water & 2 & 1.07 & 1.29 & - & 27.27 & - \\
\hline 10. & 2362-2391 & 29.00 & Water & 2 & 3.95 & 4.56 & - & 27.27 & - \\
\hline 11. & $2479-2508$ & 29.00 & Gas & 100 & 28.37 & 37.82 & 96.42 & 1.09 & 29.22 \\
\hline 12. & $2540-2592$ & 68.50 & Water & 2 & 2.00 & 2.67 & - & 27.27 & - \\
\hline 13. & $2686-2710$ & 24.00 & Water & 2 & 5.21 & 6.94 & - & 27.27 & - \\
\hline
\end{tabular}

\section{RESULTS}

Computed petrophysical properties at varying depth intervals and the well logs analyses of well A and B are presented in Table 1 and 2, Figure 2 and Figure 3 respectively. In well $\log A$, a total of eleven (11) reservoirs were analyzed and thirteen (13) reservoirs in well $\log B$, with their respective thicknesses. The total net pay thicknesses for the well logs examined are $603.50 \mathrm{~m}$ and $576.50 \mathrm{~m}$ for well $\log A$ and $B$ respectively. The resistivity of the well logs ranges from $2.05-150 \Omega m$ for $A$ and $2-200 \Omega m$ for $B$. The bulk density $\left(\ell_{b}\right)$ and the neutron porosity were obtained from the density and neutron logs respectively. 
The Bulk density values so obtained from the log and the neutron porosity were used to compute the values for the formation porosity $\left(\phi_{D}\right)$, average total porosity $\left(\emptyset_{T}\right)$ and the effective porosity $\left(\emptyset_{E}\right)$.

The ranges of the porosity of both well logs are summarized as follows $\emptyset_{D} 27.27-39.39 \%$ and $27.27-36.30 \%$ for well $\log A$ and $B$ respectively. The $\emptyset_{T}$ value of $1.3 \times 10^{-1}-37.82 \%$ and $2.25 \times 10^{-}$ $2-93.0 \%$ for well log $A$ and $B$ while $\emptyset_{E}$ value of $1.638 \times 10^{-4}-81.38 \%$ and $9.75 \times 10^{-4}-32.79 \%$ for both well $\log A$ and $B$ respectively.

The resistivity log has values that can be graded as low (water), medium (oil) and high or very high (gas), this played an important role in identifying the fluid types present in the wells. The resistivity of the water-bearing leg is the value obtained from the resistivity log on which the reservoir has the least resistivity value from top to the bottom of the well. This value is used as a reference point to all other water-bearing zones in the well logs, such that $R_{w}$ values are taken as a constant to ensure uniformity of result. In Tables 1 and 2, the $\mathrm{SHC}_{\mathrm{HC}} \mathrm{BVW}$ and BVH values range from $73.27-95.10 \%, 1.78-39.39 \%$ and $24.40-34.58 \%$ respectively for well $A$ and $77.10-97.9 \%, 0.76-33.0 \%$ and $23.36-35.53$
$\%$ for well B respectively. The values obtained in water leg resistivity and bulk density for water leg are represented in Table 3. These values were used in the grading of porosity ( $R_{w}$ for well $A$ and $B$ (Table 4).

The experimental flow chat for the study from start to finish is presented in Figure 4 in order to explain the detail procedures took in course of the study.

\section{DISCUSSIONS}

The reservoirs with higher percentages of water saturation (Sw) are termed wet reservoirs. Consequently, such reservoirs are classified as noncommercial for potential hydrocarbon $\left(\mathrm{H}_{\mathrm{c}}\right)$ exploitation. In well $A$, reservoirs (1-5 and 7) with higher percentages of water saturation (Sw) up to $100 \%$ and BVW average of $31.2 \%$ were grouped under wet reservoirs while others with very low $S_{w}$ values corresponding to high percentages of $\mathrm{S}_{\mathrm{HC}}$, very low to relatively high BVW values, were grouped under commercial reservoirs with potential hydrocarbon exploitation and production [23]. On the other hand, a well with hydrocarbon saturation $\left(\mathrm{S}_{\mathrm{HC}}\right)$ of over $50 \%$ indicates a good field for oil or gas exploration.

Table 3: Water leg parameter' for well $\log A$ and $B$

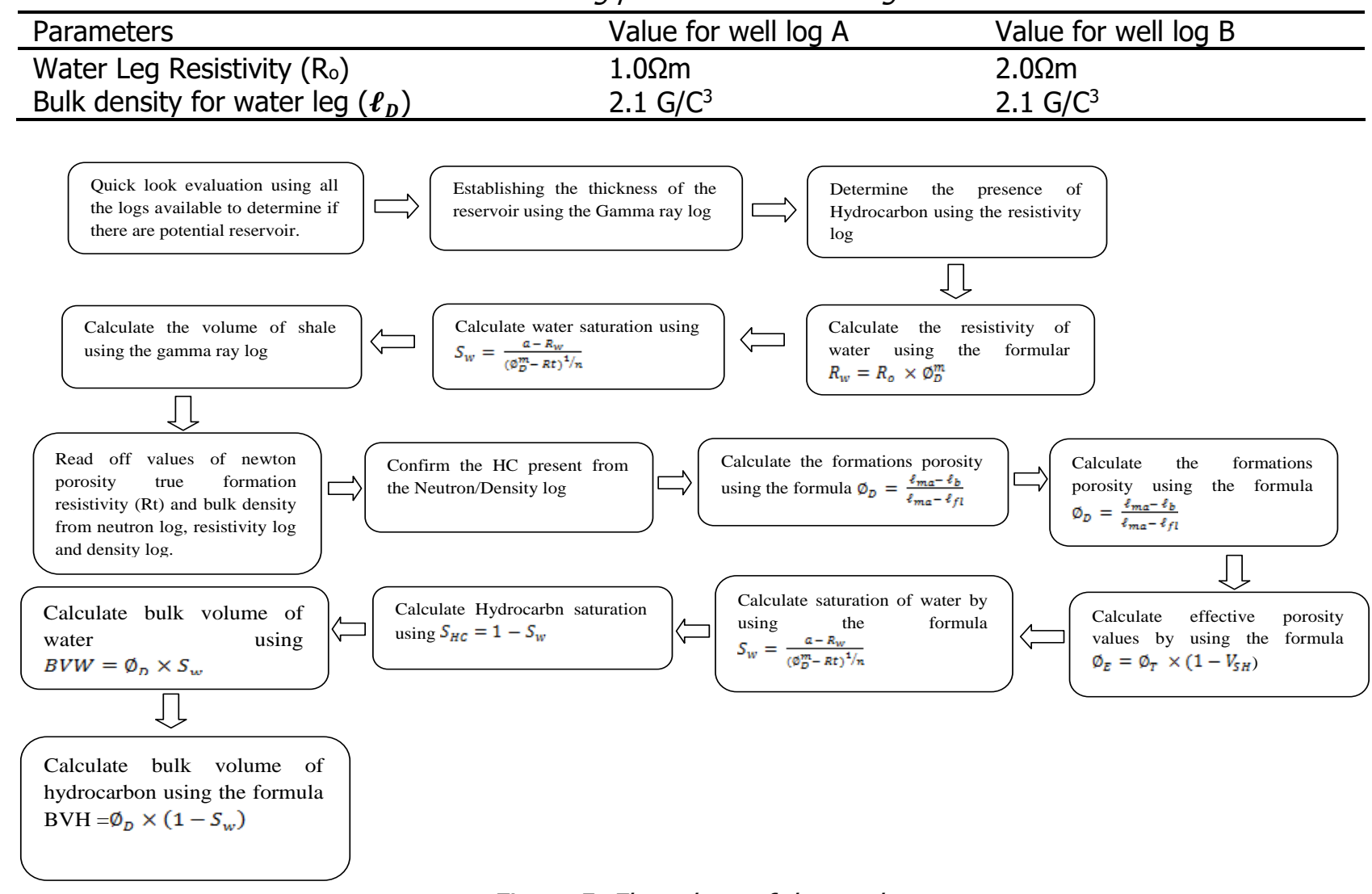

Figure 5: Flow chart of the study 
In this study, over $90 \%$ of hydrocarbon saturation (SHC) was computed making the wells excellent for oil and gas production. Conversely, reservoirs 6 , 8-9a, 10a, 10b, 11 (Table 1) with hydrocarbon saturation $\left(\mathrm{S}_{\mathrm{HC}}\right.$ ) values averaging $86.2 \%$ and $31.0 \%$ for the $\mathrm{BVH}$ reveals that well $\mathrm{A}$ has a high potential for hydrocarbon exploitation. Furthermore, their resistivity values of $60,40,40$ and $150 \Omega \mathrm{m}$ respectively with a considerably high netpay thickness of $47 \mathrm{~m}, 35 \mathrm{~m}, 44.5 \mathrm{~m}$ and $56 \mathrm{~m}$, gives it a good ground for commercial exploitation as gas reserves [24]. It was observed at a depth of $3348 \mathrm{~m}$ and a netpay thickness of $69.5 \mathrm{~m}$, with $\mathrm{S}_{\mathrm{HC}}$ of $73.3 \%$ and BVH of 24.4 there was occurrence of a Gas-Oil contact. This occurrence makes well $A$ at that point highly favourable for oil exploitation. Accordingly, the pay zones in this well are reservoirs $10 \mathrm{a}, 10 \mathrm{~b}$ and 11 , with netpay thickness, average total porosity and effective Porosity of (56.0, 69.5 and 24.0)m, (59.0, 21.0 and 93.0$) \%$ and $(49.1,15.5$ and 81.4$) \%$ respectively. Tables 1 and 2 showed values computed for porosity. From the Tables, the average total porosity of the six reservoirs is $56.18 \%$ and $42.6 \%$ effective porosity. These values reflect an excellent porosity with a very good interconnectivity within pores which enhances the viscosity and permeability, so that the bulk volume occupied by the hydrocarbon is also appreciably high to its commercial profitability [22, 25].

In well $B$, the presences of three fluids (water, oil and gas) were identified. It was observed from the result obtained that reservoir $1,5,8,9 b, 10,12$ and 13 have water saturation (Sw) values of $100 \%$ with BVW averaging $20.30 \%$ which enable its classification as wet reserves, indicating poor hydrocarbon prospect. The hydrocarbon exploitable zones in well $B$ that might be considered to be in commercial quantity correspond to reservoir $2-4 b$, $6,7,9 a$ and 11 . This was supported by its extremely high hydrocarbon saturation $\left(\mathrm{S}_{\mathrm{HC}}\right.$ ) values ranging from $77.10-97.9 \%$ averaging $90.0 \%$ coupled with the average $\mathrm{BVH}$ of $30.6 \%$. The resistivity values obtained further assists in differentiating the reserves into oil and gas potentials [24, 26]. Reservoir 2, 3, 4a and 11 with resistivity values of 200, 100, 140 and $100 \Omega \mathrm{m}$ respectively were identified as gas reserves whereas reservoir $4 b, 6$, 7 and 9a with resistivity values of 16,4 and $8 \Omega \mathrm{m}$ were identified as oil reserves. Reservoir 11 with net pay thickness, average total porosity and effective porosity of $29.0 \mathrm{~m}, 37.8 \%$ and $28.37 \%$ respectively was identified as the pay zone. The average total porosity and effective porosity for these hydrocarbon productive reserves were also measured. The result of $\emptyset_{T} 37.82 \%$ and $\emptyset_{E}$ of $30.6 \%$ made them excellent reserves for gas production which strongly correlates with [27]. However, the value of $\emptyset_{T} 11.6 \%$ and $\emptyset_{E} 9.2 \%$ made them poor for oil reserves.

The values of oil reservoirs show an average total porosity and effective porosity as poor, implying that, though the other petrophysical properties evaluated suggests the availability of oil in these reserves, but the poor interconnection of the pores and average total porosity render the reservoir noncommercial reserves for oil exploitation. Conversely, the gas reserves which showed excellent total and effective porosities made the reserves of high commercial potentials for gas production.

In summary, three contacts; Gas Water Contact (GWC), Gas Oil Contact (GOC) and Oil Water Contact (OWC) were present in the wells. These parameters are essential for volumetric calculations like the volume of producible Hydrocarbon. Additionally, GOC and GWC can be defined at depth at which the neutron porosity significantly decreases and density of porosity increases with interval upward movement in the reservoir. In well A, the GWC and GOC were found at a depth of $2967.5 \mathrm{~m}$ and $3348 \mathrm{~m}$ respectively. On the contrary, the GOC and OWC were encountered during the drilling for GOC and OWC at a depth of $1715 \mathrm{~m}$ and $2286 \mathrm{~m}$ respectively.

It was observed that after correlation of both wells with equal depth of penetration at $2450 \mathrm{~m}$, that gas reservoir exist for both wells while water reservoir occurred at $2350 \mathrm{~m}$ and $2500 \mathrm{~m}$ respectively. The depth of $2150 \mathrm{~m}$ was identified as a non-resistive but highly conductive zone. Furthermore, correlation of well $A$ and $B$ (Figure 7) revealed that well $B$ is deeper than well $A$. This suggests an earth's displacement of the strata which is an indication of the presence of a fault [2425]. This can assist in unveiling the stratigraphy of these wells in accordance with the principle of superposition [9]. Since the strata has been disturbed as observed from the correlation of the wells; it would be impossible to determine the relative age of the strata by the application of the law of superposition. 

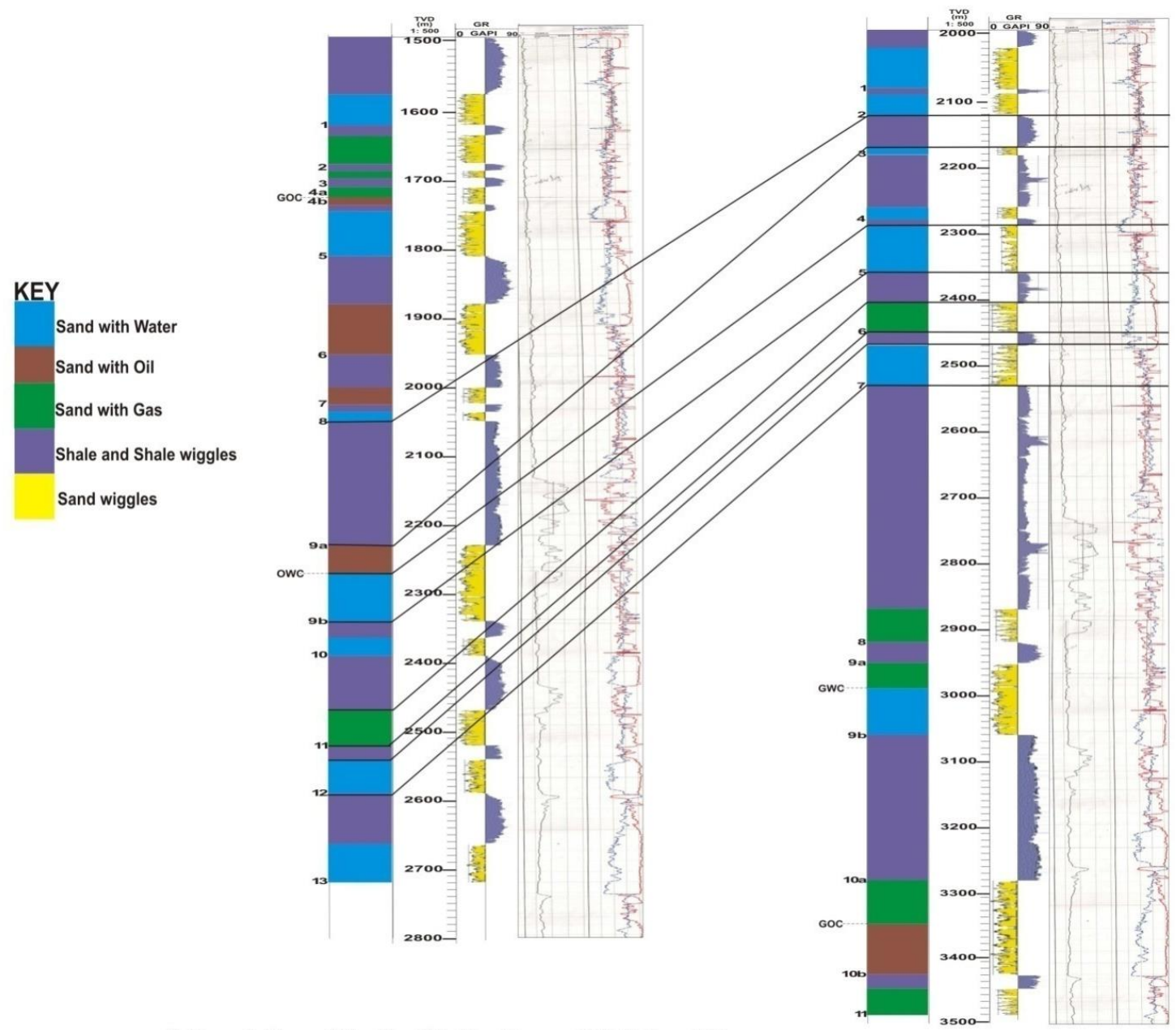

Figure 6: Correlation of the prolific section of well $\log A$ and B onshore Niger Delta

\section{CONCLUSION}

From the petrophysical evaluation of wells $A$ and $B$ in $\mathrm{E}$-field onshore Niger Delta, the excellent total porosity $\left(\varnothing_{T}\right)$ and effective porosity $\left(\emptyset_{E}\right)$ value of the gas reservoir together with other petrophysical properties evaluated reveals that they have high commercial potential for gas exploitation and production. In addition, the correlation of well $A$ and $B$ showed that both wells have a gas reserve occurring at a depth of $2450 \mathrm{~m}$ and well $B$ was found to be deeper than well $A$ which indicates the presence of faults. The pay zones for well $A$ are reservoirs 10a and 10b, which are gas and oil reserves respectively. Similarly, the pay zone in well $B$ is reservoir 11 , which is a gas reserve. Ultimately, well $A$ is suited for both oil and gas exploitation, though mainly gas reserves were observed while well B was strictly a gas reserves. Since E-field is predominately a gas field, it is recommended that it should be used for power generation in Nigeria.

\section{ACKNOWELEDGEMENTS}

The author would like to thank the Department of Geology, University of Benin, Nigeria for their technical support in making sure that the research work was completed successfully. We would also like to appreciate Professor Okpeseyi I. Imasuen and Dr. F.A Lucas for their useful suggestions. The research was fully sponsored by the researchers; no external funding was received.

\section{REFERENCES}

[1] Short, KC and Stauble, AJ "Outlines of geology of Niger Delta" AAPG bulletin, Vol. 51, 1967, p761 $-779$.

[2] Allen, JR L "Late Quaternary Niger delta and adjacent areas sedimentary environments and lithofacies" AAPG Bulletin, Vol. 53, 1970, p547 -600 .

[3] Oomkeens, E "Lithofacies relations in the Late Quaternary Niger Delta complex sedimentology" AAPG bulletin, Vol. 59, 1974, p195- 222. 
[4] Weber, KJ and Daukoru EM "Petroleum Geology of the Niger Delta" AAPG Bull. Vol.62 (2), 1975, p295-306.

[5] Evamy, BD "Hydrocarbon Habitat of the tertiary Niger Delta" AAPG bulletin, Vol. 62, 1978, p1 39.

[6] Udosen C, Etok, AS and George, IN (2009) Fifty years of oil exploration in Nigeria: the paradox of plenty. Global Journal of Social Sciences, Vol. 8 (2) 2009, p 37-47

[7] Burke K "Long shore drifts sub marine canyons and submarine fans in the development of Niger Delta" AAPG bulletin Vol. 56, 1972 p1975 1983

[8] Whiteman, AJ (1982) Nigeria and its petroleum geological resources and potential. Graham and Trotman, London, $1^{\text {st }}$ edn (2) 1982, p394

[9] Akande, SO., Ojo, OJ., and Adekeye, OA "Stratigraphic evolution and petroleum potentials of middle Cretaceous sediments in the Lower and Middle Benue trough, Nigeria: insight from new source rock facies evolution" Petroleum Technology Development Journal, Vol. 1, 2011 p2-30

[10] Doust, $\mathrm{H}$ and Omatsola, ME "Niger: In Edwards JD Santogros: PA (Eds) Divergent passive margin basin" AAPG Memoir 48, 1989 Tulsa Oklahoma.

[11] Weber, KJ "Hydrocarbon distribution pattern in Niger Growth fault structure control by structural style and stratigraphy" International Conference of AAPG, 1986 p.165 - 174.

[12] Nwajide, CS "Geology of Nigeria sedimentary basins" CSS Bookshops Limited $1^{\text {st }}$ Edn. 2013, p 565

[13] Ekweozor, CM and Daukoru, NM (1984) Petroleum source bed evaluation of Tertiary Niger Delta. AAPG Bulletin, Vol. 68 (3), 1984 p391 - 394.

[14] Ilevbare, $M$ "Lithostratigraphic and petrophysical evaluation of well $A$ and $B$ in $E-$ field onshore Niger Delta, using wireline logs" M.Sc Thesis, University of Benin, Nigeria, 2014, p.70

[15] Lambert- Aikhionbare, DO and Ibe, AC "Petroleum source bed evaluation of Tertiary Niger Delta Discussion" AAPG bulletin, Vol. 68 (3), 1984, p387- 394.

[16] Society of Professional well log Analyst "Glossary of terms and expressions used in well logging" Houston, Texas (SPWLA) 1975, p86
[17] Amao, AM "Introduction to formation evaluation" Well Logging, PGE, Vol. 492, 2013 p1-27

[18] Prensky, S "What's new in well logging and formation evaluation" Researchgate, https://www.researchgate.net/publication/281 874916, April 2015 p123-127

[19] Schon, J "Basic well logging and formation evaluation" Book Boom The E-Book Company (1 ${ }^{\text {st }}$ Edn), 2015, p178. https://www.bookboom.com

[20] Oyo-Ita OE, Ekpo, BO and Simoneth BRT "Distribution and sources of aliphatic hydrocarbon and ketones in sediments" $A A P G$ Bulletin Vol. 67, 2008 p252-258.

[21] Bosma JP "An Introduction to basics of log evaluation" $2^{\text {nd }}$ Edn, 2000 p28.

[22] Clark, N J and Shearin , H M "Formation evaluation of oil and gas reservoirs" Core Laboratories, -Inc., Dallas, Texas. Paper number 582-G, 2019 p 1-11

[23] Azari M, Hashmi G, Hamza F, Tahani H, Quirein J, Ghalambor A "Integrated formation evaluation with advanced well logs straddlePacker Mini drill stem tests and a surface shut in well test to reevaluate a mature tight field" International Conference and Exhibition on Formation Damage Control: Lafayette, LA SPE, 199320-MS, 2020, p1-20

[24] Ellafi A, Ba Geri M, Bubach B, Jabbari H "Formation evaluation and hydraulic fracture modeling of unconventional reservoirs: Sab'atayn basin case study" America Rock Mechanics Association-ARMA, 2019, p.1-11

[25] Sharma N "Comparison of classical Archie's equation with Indonesian equation and use of crossplots in formation evaluation: A case study" Bianual International Conference and Exposition on Petroleum Geophysics, Hyderabad 2010, p1-6

[26] Okiotor ME Eghodalo EJ "Geotechnical appraisal of the Mamu shales exposure around Igodor in the Benin flank of Anambra basin" Journal of Applied and Environmental Management, Vol. 24 (3), 2020 p.489-493.

[27] Omontese OS, Imasuen OI, Uzoegbu MU, Lucas FA, Omorogieva OM "Biomarker geochemistry of Nkporo shale from Ndi-Owerre in the Afikpo Basin, Southeast Nigeria" International Journal of Geology and Mining, Vol. 5 (2), 2019 p.281286. 